\title{
Petrified ears due to auricular ossification: an underreported clinical sign in acromegaly
}

\author{
Avivar Awasthi ำ, Neeti Agrawal, Partha Pratim Chakraborty ํㅜ, Animesh Maiti
}

Endocrinology \& Metabolism, Medical College and Hospital Kolkata, Kolkata, West Bengal, India

\section{Correspondence to} Dr Partha Pratim Chakraborty; docparthapc@yahoo.co.in

Accepted 3 December 2021

\section{DESCRIPTION}

Acromegaly due to growth hormone (GH) secreting pituitary macroadenoma (Hardy II A, KNOSP 3) had been diagnosed in a 43 -year-old man, and he had subsequently been treated with endoscopic trans-sphenoidal surgery (twice in an interval of 6 months) and gamma knife radiosurgery (4 months after the second surgery). Due to persistent disease, he visited us for long-acting somatostatin analogue therapy 2 years after the first surgery. Diabetes mellitus (DM) was diagnosed 4 years back, which was adequately controlled with metformin. In addition, he was on levothyroxine and hydrocortisone supplementation due to postoperative central hypothyroidism and hypoadrenalism (morning cortisol: $3.1 \mu \mathrm{g} / \mathrm{dL}$ ). Preoperative morning and synacthen-stimulated serum cortisol were $8.34 \mu \mathrm{g} / \mathrm{dL}$ and $20.2 \mu \mathrm{g} / \mathrm{dL}$, respectively. $\mathrm{He}$ complained of occasional bilateral auricular pain for many years, preceding his pituitary surgery and diagnosis of DM. Clinical examination revealed thick lips, broad nose, seborrhea, acral enlargement and petrified and tender ears (figure 1). CT scan documented bony density (Hounsfield unit: $>1100$ ) over both auricular cartilages (figure 2), which was subsequently confirmed with 3D reconstruction (figure 3). Ossification with cortical and trabecular components was evident on X-ray (figure 4). Elevated serum insulin-like growth factor- $1(543 \mathrm{ng} / \mathrm{mL}$ (Ref.: 101-267)) and unsuppressed postglucose GH (1 hour: $10.9 \mathrm{ng} / \mathrm{mL}$; 2 hours: $10.7 \mathrm{ng} / \mathrm{mL}$ ) confirmed active disease. Serum calcium $(8.7 \mathrm{mg} /$ $\mathrm{dL})$, phosphate $(3.7 \mathrm{mg} / \mathrm{dL})$ and intact parathormone (iPTH) $(30.8 \mathrm{pg} / \mathrm{mL})$ were within normal limits. His glycated haemoglobin (HbA1c) was

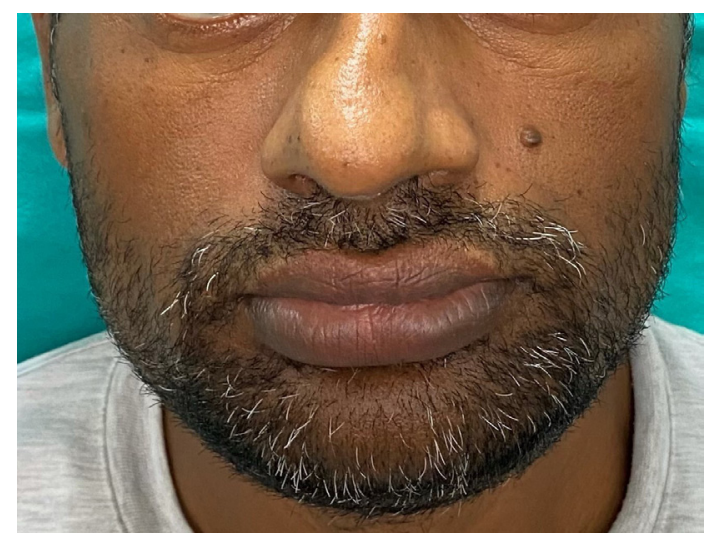

Figure 1 Broad nose and thick lips suggesting hypersomatotropism.

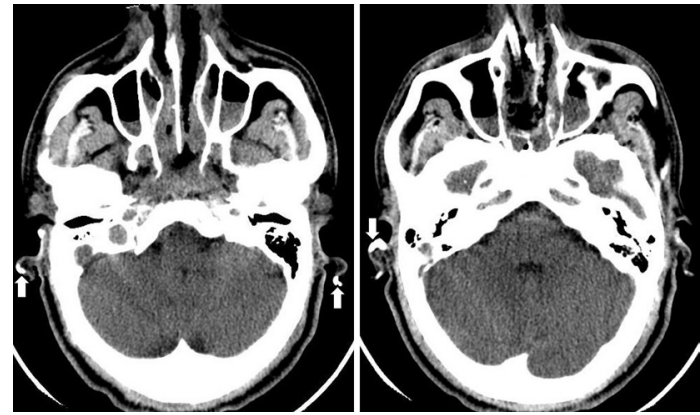

Figure 2 Non-contrast CT head axial view reveals bony density over bilateral auricular cartilages (arrows).

$6.8 \%$ and urine spot albumin creatinine ratio was $22 \mathrm{mg} / \mathrm{g}$.

Petrified or stony hard pinnae result from calcification or ossification of the elastic auricular cartilages. This is commonly associated with trauma, frostbite or inflammation, and rarely with endocrinopathies. Endocrine causes of such conditions include adrenal insufficiency (both primary and secondary), acromegaly, DM, thyrotoxicosis, hypothyroidism, pseudohypoparathyroidism (Albright's hereditary osteodystrophy) and hyperparathyroidism (primary and secondary). Adrenal insufficiency, either primary or secondary, is the most frequently described endocrine cause associated with petrified ears. ${ }^{1-3}$ True auricular ossification, in which the normal cartilaginous structures are replaced by bone, is rare and may be encountered in occasional patients with Addison's disease or acromegaly. ${ }^{2}$ Ectopic calcification of the auricular cartilages on the other hand is relatively common and is of two types: dystrophic (deposition of calcium

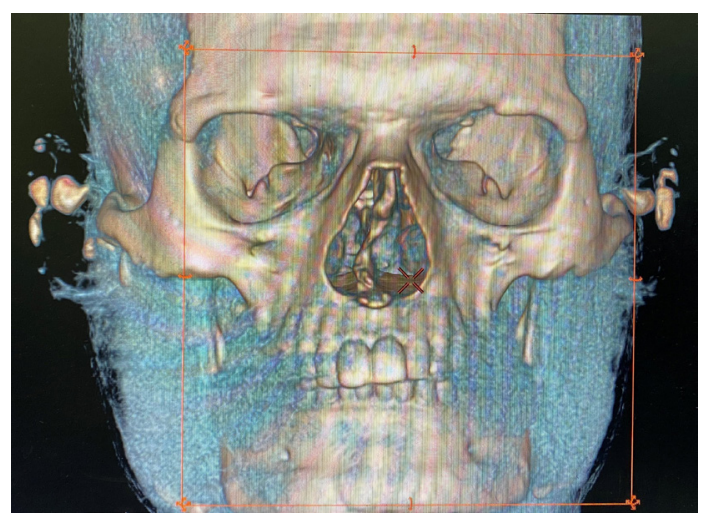

Figure 3 CT scan with 3D reconstruction of face showing bony density over both pinnae. 


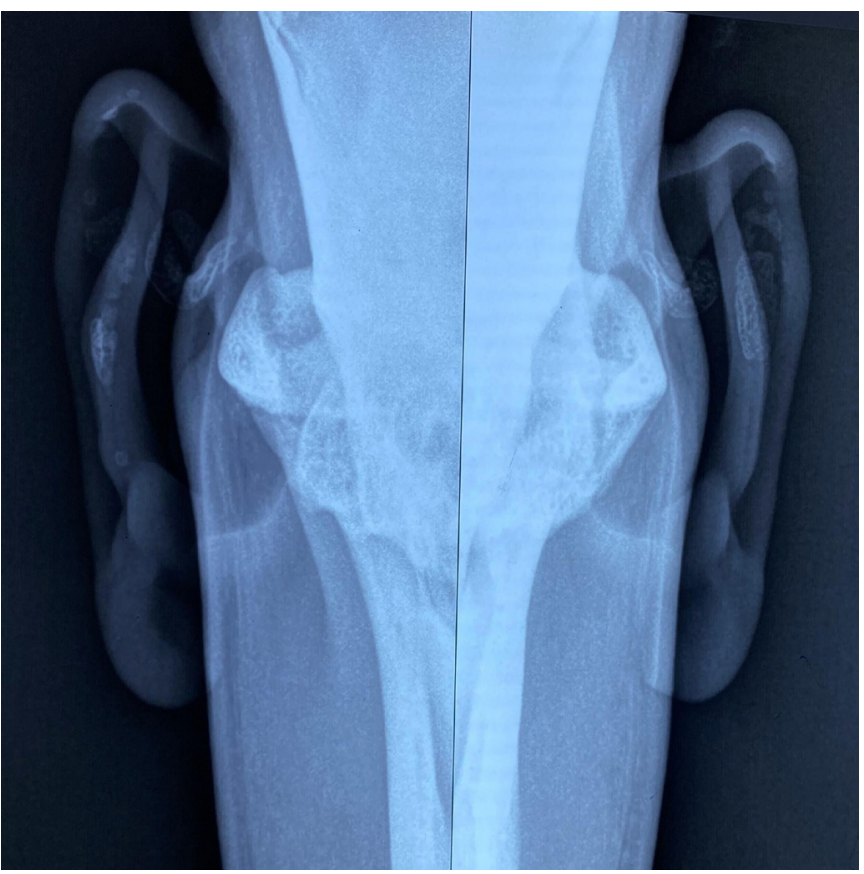

Figure 4 X-ray skull revealing ossification of bilateral auricular cartilages with cortical and trabecular components.

into damaged tissue with normal calcium and/or phosphate homeostasis) and metastatic (altered calcium and/or phosphate metabolism with involvement of healthy tissue). DM may give rise to dystrophic calcification due to diabetic microangiopathy. The aforementioned endocrine diseases are also associated with metastatic calcification. The underlying mechanism(s) of cartilage ossification or calcification in most of the endocrinopathies, however, is unclear as altered serum concentration of calcium and/or phosphate is inconsistent. Demonstration of both cortical and trabecular components on high-definition X-ray and positive bone scan differentiate ossification from calcification. However, definitive diagnosis is established only with histology. Whole body bone scintigraphy with ${ }^{99 \mathrm{~m}} \mathrm{Tc}-\mathrm{MDP}$ with single-photon emission CT (SPECT) revealed tracer uptake in the bilateral pinna, suggesting true ossification in this patient (figure 5). Increased tracer uptake was also seen in the costal cartilages indicating possible calcification there as well. Ossification of pinna was subsequently confirmed on excision biopsy specimen (figure 6).

Acromegalic develop proliferative as well as degenerative changes of the cartilages. The areas of degeneration may subsequently undergo calcification with/without ossification.

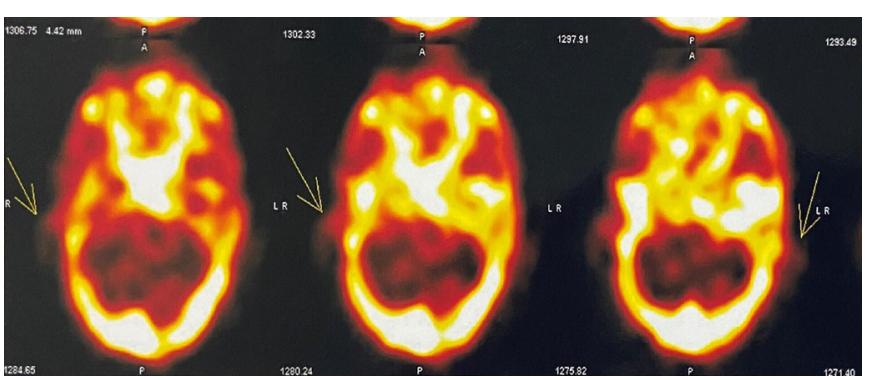

Figure 5 Increased tracer uptake over bilateral pinnae in ${ }^{99 \mathrm{~m}} \mathrm{Tc}-\mathrm{MDP}$ SPECT images (arrows).

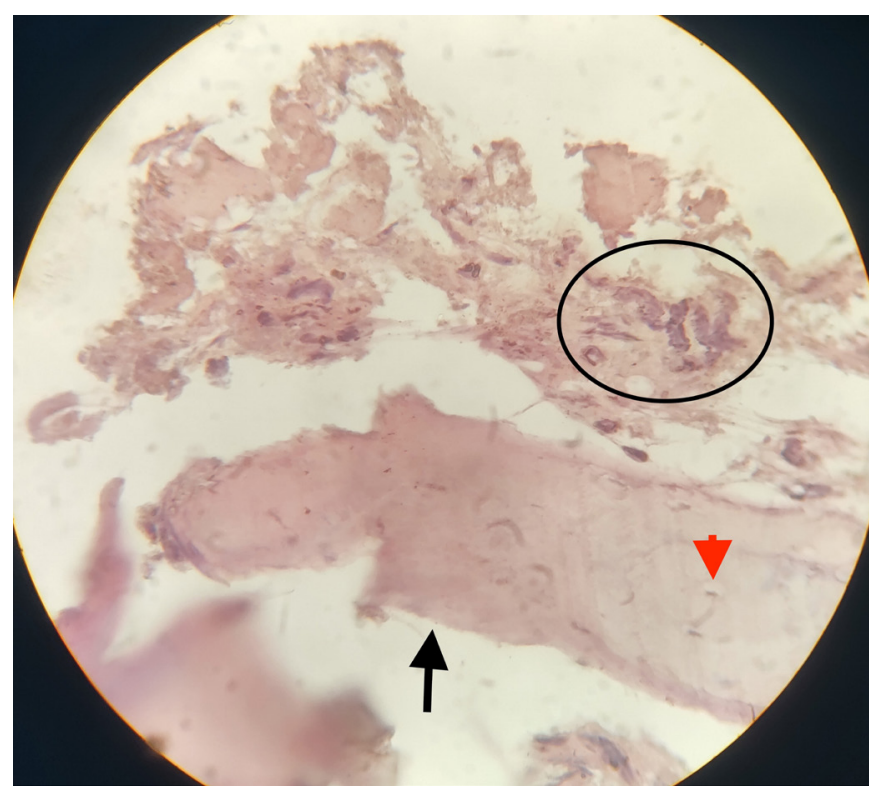

Figure 6 H\&E stain of the wedge biopsy specimen obtained from right auricle showing trabeculae (black arrow), osteocytes in lacunae (red arrowhead) and haematopoietic cells (blue dots within the black circle).

\section{Learning points}

- Petrified or stony hard pinna due to calcification or ossification of auricular cartilages is a rarely encountered clinical sign of underlying endocrinopathy.

- Adrenal insufficiency and acromegaly may give rise to true ossification of the auricular cartilages. Presence of cortical and trabecular bony components on X-ray and positive technetium bone scan separate ossification from calcification.

- Stony hard pinnae may indicate underlying hypersomatotropism or secondary hypocortisolism in patients with acromegaly; hence clinicians should be vigilant to look for this sign, particularly in those without overt clinical features.

Cartilages of the ribs, intervertebral discs, larynx and trachea are commonly involved by this process; involvement of auricular cartilages is rarely encountered. Petrified ears in acromegaly may result from elevated growth hormone activity per se or may be a manifestation of associated central adrenal insufficiency or secondary DM or rarely in hyperparathyroidism in patients with multiple endocrine neoplasia 1 syndrome. Auricular ossification in this patient was a manifestation of acromegaly itself as there was no temporal association between ear discomfort and onset of hypoadrenalism or DM. Petrified ears due to ossification is probably an underreported clinical sign in acromegaly and may at times serve as a useful clinical tool to suspect underlying hypersomatotropism or hypoadrenalism in absence of typical features in patients with acromegaly with/ without hypopituitarism.

Contributors $A A, N A, P P C$ and $A M$ were involved in diagnosis and management $A A$ and NA evaluated the patient. AA and PPC did the literature search and wrote the manuscript.

Funding The authors have not declared a specific grant for this research from any funding agency in the public, commercial or not-for-profit sectors. 
Competing interests None declared.

Patient consent for publication Consent obtained directly from patient(s).

Provenance and peer review Not commissioned; externally peer reviewed.

Case reports provide a valuable learning resource for the scientific community and can indicate areas of interest for future research. They should not be used in isolation to guide treatment choices or public health policy.

\section{ORCID iDs}

Avivar Awasthi http://orcid.org/0000-0002-3535-4920

Partha Pratim Chakraborty http://orcid.org/0000-0002-3316-4525

\section{REFERENCES}

1 Gordon DL. Calcification of auricular cartilage. Arch Intern Med 1964:113:23-7.

2 Aw J, Davies R, Cook J-L. Stone deaf: the petrified ear-case report and review of the literature. Radio/ Case Rep 2011:6:430.

3 Buikema KE, Adams EG. A rare case of petrified ear. Case Rep Dermatol Med $2012 ; 2012: 1-4$.

Copyright 2021 BMJ Publishing Group. All rights reserved. For permission to reuse any of this content visit

https://www.bmj.com/company/products-services/rights-and-licensing/permissions/

BMJ Case Report Fellows may re-use this article for personal use and teaching without any further permission.

Become a Fellow of BMJ Case Reports today and you can:

- Submit as many cases as you like

- Enjoy fast sympathetic peer review and rapid publication of accepted articles

- Access all the published articles

Re-use any of the published material for personal use and teaching without further permission

Customer Service

If you have any further queries about your subscription, please contact our customer services team on +44 (0) 2071111105 or via email at support@bmj.com.

Visit casereports.bmj.com for more articles like this and to become a Fellow 